\title{
Endothelin A Receptor Blockade Improves Endothelium-Dependent Relaxation in Obese Woman
}

\author{
K. GRADIN ${ }^{1}$, B. PERSSON ${ }^{2}$ \\ ${ }^{1}$ Department of Pharmacology, University of Gothenburg, Sahlgrenska Academy, Gothenburg, \\ Sweden, ${ }^{2}$ Division of Internal Medicine, Sahlgrenska University Hospital, Sahlgrenska, \\ Gothenburg, Sweden
}

Received November 21, 2017

Accepted April 18, 2018

\section{Summary}

Hypertension in obesity is associated with increased insulin resistance, vascular mass and body mass index (BMI). The purpose of the study was to visualize endothelin-1 (ET-1) mediated constriction in arteries isolated from subcutaneous adipose tissue from obese hypertensive women previously operated by gastric bypass. Functional studies were conducted in a microvascular myograph. Expressed as percentage of contraction elicited by $124 \mathrm{mM} \mathrm{KCl}$ concentration-response curves for ET-1 were shifted leftward in arteries from obese hypertensive patients compared to healthy normotensive subjects. The vasodilator response to the ET-1 antagonist BQ123 $(1 \mu \mathrm{M})$ was significantly higher in arteries from obese hypertensive patients $(p<0.001)$. BQ123 induced relaxation was inhibited by NO synthase inhibitor L-NAME (0.1 nM). Preincubation with $\mathrm{BQ} 123$ enhanced the relaxation induced by acetylcholine (ACh; $0.1 \mathrm{nM}-0.1 \mathrm{mM})(p<0.001)$, but not that induced by NO donor sodium nitroprusside (SNP; $0.1 \mathrm{nM}$ $0.1 \mathrm{mM}$ ), in arteries from obese hypertensive patients. The present study show that hypertension yet prevail after gastric bypass surgery and the $\mathrm{ET}_{\mathrm{A}}$ receptor antagonist $\mathrm{BQ} 123$ may be a useful tool in reducing blood pressure in obese hypertensive patients.

\section{Key words}

Human small arteries • Endothelin • Endothelium • BQ123 • Nitric oxide $\bullet$ Women $\bullet$ Obesity

\section{Corresponding author}

B. Persson, Division of Internal Medicine, Sahlgrenska University Hospital, Sahlgrenska, 40583 Gothenburg, Sweden. E-mail: bengt.erik.persson@telia.com

\section{Introduction}

Patients with essential hypertension have impaired endothelium-dependent vasodilatation mainly due to decreased bioavailability of endothelial nitric oxid (NO) (Gradin et al. 2003, Panza et al. 1990). Endothelial dysfunction has been associated with the development of atherosclerosis and other vascular complications observed in hypertensive patients. The mechanisms leading to impaired endothelial function in obese hypertensive vessels have not been fully elucidated. A disruption of the critical equilibrium between opposing forces may result in thickening of the vascular wall and may predispose the vascular smooth muscle to increased tone and decreased vasomotion (Panza et al. 1993). Among substances produced by vascular endothelial cells is endothelin (ET-1) a powerful vasoconstrictor peptide (Yanagisawa et al. 1988). ET-1 exerts its vasoactive effects through interaction with 2 receptor subtypes, $\mathrm{ET}_{\mathrm{A}}$ and $\mathrm{ET}_{\mathrm{B}}$ (Luscher and Noll 1995, Sakurai et al. 1990). The $\mathrm{ET}_{\mathrm{A}}$ receptor is a classic G-protein-coupled receptor, involving a pertussis toxin-insensitive G-protein at the receptor site, localized to the vascular smooth muscle cells (VSMC) (Böhm and Pernow 2007, Lin et al. 1991). The $\mathrm{ET}_{\mathrm{A}}$ receptor appears to be the dominant receptor mediating vasoconstriction to endogenous and exogenous ET-1 and accounts for the role of ET-1 in basal vascular tone in humans under physiological conditions (Seo et al. 1994, Warner 1999, Haynes and Webb 1994). Moreover, in isolated vessel studies and in vivo $\mathrm{ET}_{\mathrm{A}}$ receptors play an integral role in vasoconstriction to endogenous or exogenous ET-1. Vascular $\mathrm{ET}_{\mathrm{B}}$ receptors are localized on 
VSMC and endothelial cells (Maguire et al. 2001). Previous studies have described that nonselective antagonism of $\mathrm{ET}_{\mathrm{A} / \mathrm{B}}$ receptors resulted in a significant vasodilator response in hypertensive patients, but not in healthy controls (D'Orleans-Just et al. 2002). This indicates that increased activity of the ET-1 system indeed contributes to the augmented vascular tone of patients with hypertension.

Vascular health declines earlier in aging male subjects compared to female subjects (Derbyshire and Marietta 2012). Thus, estrogen regulates a number of signaling pathways that are protective to the vessel structure and function, both during short term and in the long term (Tang and Vanhoutte 2012). Major hormonal changes associated with cessation of function or menopause, such as circulating estrogen and progesterone levels contribute to vascular dysfunction in women via loss of the beneficial mechanisms (Celemajor et al. 1994). Recent results describe a more profound association between total or abdominal adiposity and arterial properties in women than in men (Quio et al. 2008).

The purpose of this study was to investigate the contribution of the $\mathrm{ET}_{\mathrm{A}}$ receptor to vascular reactivity and obese hypertension after gastric bypass surgery. Since the hypertension is increased the response to the $\mathrm{ET}_{\mathrm{A}}$ receptor antagonist $\mathrm{BQ123}$ was characterized in subcutaneous arteries isolated from obese hypertensive woman compared to arteries from healthy woman. Endothelium cell dysfunction seems to contribute to the vasoconstriction.

\section{Materials and Methods}

\section{Subjects}

Obese women aged $54.8 \pm 2.4$ years who had undergone gastric bypass surgery within the last 2 years and with a documented history of hypertension (blood pressure $>140 / 90 \mathrm{~mm} \mathrm{Hg}$ ), at the outpatient clinic of the Department of Plastic surgery, Sahlgrenska University Hospital for removal of excess abdominal adipose tissue were recruited in the study. None of the patients had a history of diabetes.

A group of healthy women (control group) matched for age was recruited from the same department to serve as a control group. The subjects were scheduled for esthetic surgery.

Each subject was screened by clinical history body mass index, blood pressure and routine chemistry.
The control subjects had no history of hypertension, and none were taking medications at the time of the study. The study protocol was approved by the Swedish ethical board in Gothenburg and all participants gave their written informed consent.

\section{Baseline measurements}

All measurements were collected in the morning. Blood samples were collected and a physician measured systolic and diastolic blood pressure twice in the left arm of the subject in the sitting position using a standardized protocol. The average of 2 such readings constituted the examination blood pressure and body mass index.

\section{Tissue preparation}

During abdominal surgery of obese and control subjects, $5 \mathrm{~g}$ of subcutaneous adipose tissue was removed, put in prechilled salt solution and immediately transported to the laboratory for functional studies. Arteries in the adipose tissue were carefully freed from surrounding tissue. Segments of $2 \mathrm{~mm}$ length were mounted onto stainless wires and suspended in $5 \mathrm{ml}$ microvascular myograph baths (Danish Myotechnology, Aarhus, Denmark). The tissue baths were temperature controlled $\left(37^{\circ} \mathrm{C}\right)$ and contained physiological salt solution (PSS) of the following composition (mM): $\mathrm{NaCl}$ 119, $\mathrm{NaHCO}_{3} 25$, glucose 5.5, $\mathrm{KCl}$ 4.7, $\mathrm{CaCl}_{2} 2.5$, $\mathrm{KH}_{2} \mathrm{PO}_{4} 1.18, \mathrm{MgSO}_{4} 1.17$ and ethylenediaminetetraacetic acid (EDTA) 0.026. KPSS was similar to PSS except that $\mathrm{NaCl}$ was exchanged with $\mathrm{KCl}$ on an equimolar basis. Solutions were equilibrated with $5 \% \mathrm{CO}_{2}$ in $\mathrm{O}_{2}$ to maintain a $\mathrm{pH}$ of 7.4. The vessels were allowed to stabilize for $60 \mathrm{~min}$. The relation between resting wall tension and internal circumference $\mathrm{L}_{100}$ corresponding to a transmural pressure of $100 \mathrm{~mm} \mathrm{Hg}$ for a relaxed vessel in situ was calculated. The vessels were set to the internal circumference $L_{1}$, given by $L_{1}=0.9$.

\section{Recording of mechanical activity}

The contractile ability of the vessels was tested by stimulating with $124 \mathrm{mM}$ KPSS until reproducible responses were obtained; i.e. when the arteries developed contraction was within $10 \%$ of the previous contraction to KPSS. In most experiments this was reached with a third stimulation to KPSS.

Cumulative concentration response curves were obtained by addition of endothelin-1 (ET-1: 1 pM $0.1 \mathrm{mM}$ ) in arteries under baseline conditions or following incubation with the $\mathrm{ET}_{\mathrm{A}}$ receptor antagonist BQ123 $(0.3 \mu \mathrm{M}, 1 \mu \mathrm{M}$ and $3.0 \mu \mathrm{M})$ for $30 \mathrm{~min}$ was 
investigated, since limited amount of artery was available the effect of $1 \mu \mathrm{M}$ BQ123 was determined in these preparations.

Concentration response curves to the endothelium-dependent dilator acetylcholine (ACh: $0.1 \mathrm{nM}-0.1 \mathrm{mM}$ ) and the endothelium-independent dilator sodium nitroprusside (SNP; $0.1 \mathrm{nM}-0.1 \mathrm{mM}$ ), in arterial segments precontracted with phenylephrine (Phe) (300 nM) for $15 \mathrm{~min}$. The relaxations were determined in the absence and presence of the selective $\mathrm{ET}_{\mathrm{A}}$ receptor antagonist BQ123 $(1 \mu \mathrm{M})$. The relaxations induced by ACh were in addition determined following blockade of NOS by N-mono-methyl-L-arginine, L-NAME (0.1 nM). All chemicals were purchased from Sigma. Stock solutions were prepared and stored at $-20{ }^{\circ} \mathrm{C}$ and fresh dilutions were prepared daily.

\section{Analysis of data and statistics}

Mechanical responses of vessels were measured as force and expressed as active wall tension (T) which is the increase in force above baseline (F) divided by twice the segment length. The contractile response to ET-1 is expressed as a percentage of that induced by KPSS. Relaxations are expressed as percentages of the precontractile tone. Sensitivity to the agonists is given as $\mathrm{pD}_{2}=-\log \mathrm{EC} 50(\mathrm{M})$.

Table 1. Clinical characteristics of the study participants.
The results from the vessel studies are expressed as means \pm SEM and $n$ represents the number of arteries (one/subject). Clinical characteristics of participating woman are presented as means \pm SD. Statistical differences between arteries in each group were tested with the use of Student's paired or unpaired t test when appropriate. Statistical differences yielding p values less than 0.05 were considered significant.

\section{Results}

\section{Study subject characteristics}

Clinical characteristics of control subjects and obese hypertensive patients are presented in Table 1. Systolic and diastolic blood pressure was significantly higher in obese hypertensive patients compared to healthy control subjects. Blood pressure taken prior to the gastric bypass surgery was $165 \pm 3.2 / 91.9 \pm 1.9 \mathrm{~mm} \mathrm{Hg}$. Thus, blood pressure remained significantly elevated (AFTER) the gastric bypass surgery. The obese patients had significantly higher BMI and lower high density lipoprotein cholesterol than the control group at follow-up (Table 1). Fasting blood glucose, HbA1c and low density lipoprotein cholesterol did not differ between the groups.

\begin{tabular}{lcc}
\hline & Control subjects & Obese hypertensive subjects \\
\hline Age, years & $55.9 \pm 1.3$ & $54.80 \pm 2.43$ \\
Weight, $\mathrm{kg}$ & $70.9 \pm 2.7$ & $106.4 \pm 3.1^{* * *}$ \\
Height, $\mathrm{cm}$ & $163.3 \pm 2.4$ & $165.0 \pm 1.3$ \\
Body mass index, $\mathrm{kg} / \mathrm{m}^{2}$ & $20.50 \pm 0.32$ & $30.70 \pm 0.94^{*}$ \\
Biochemical features & & \\
Brain natriuretic peptide, $\mathrm{pg} / \mathrm{ml}$ & $27.13 \pm 5.65$ & $41.63 \pm 18.52^{* *}$ \\
Fasting glucose, $\mathrm{mmol} / \mathrm{l}$ & $5.11 \pm 0.14$ & $5.26 \pm 0.25$ \\
HbA1c, $\mathrm{mmol} / \mathrm{mol}$ & $3.75 \pm 0.23$ & $4.09 \pm 0.17$ \\
HDL cholesterol, mmol/l & $1.74 \pm 0.65$ & $3.55 \pm 0.17^{*}$ \\
LDL cholesterol, $\mathrm{mmol} / \mathrm{l}$ & $3.56 \pm 0.32$ & $3.28 \pm 0.33$ \\
Triglycerides, $\mathrm{mmol} / \mathrm{l}$ & $1.34 \pm 1.51$ & $1.51 \pm 0.34$ \\
Morphological measurements & & $154.4 \pm 3.5^{* * *}$ \\
Systolic blood pressure, $\mathrm{mm} \mathrm{Hg}$ & & $95.1 \pm 2.1^{* * *}$ \\
Diastolic blood pressure, $\mathrm{mm} \mathrm{Hg}$ & $112.9 \pm 1.6$ &
\end{tabular}

Values are means $\pm \mathrm{SD} . * \mathrm{p}<0.05, * * \mathrm{p}<0.001, * * * \mathrm{p}<0.0001$ significant differences vs. healthy control subjects ( $\mathrm{n}=8$ ). ET-1, endothelin-1; LDL, low-density lipoprotein; HDL, high-density lipoprotein. 
Table 2. Effect of BQ123 (1 $\mu \mathrm{M})$ on ACh and SNP relaxation of subcutanouse small arteries.

\begin{tabular}{lcccc}
\hline & \multicolumn{2}{c}{ Control subjects } & \multicolumn{2}{c}{ Obese hypertensive subjects } \\
\cline { 2 - 5 } Drug & Rmax \% & $\mathbf{p D}_{\mathbf{2}}$ & $\mathbf{R m a x} \%$ & $\mathbf{p D}_{\mathbf{2}}$ \\
\hline ACh & $92.6 \pm 1$ & $7.93 \pm 0.1$ & $51.5 \pm 3^{*}$ & $7.97 \pm 0.1^{*}$ \\
$A C h+B Q 123$ & $98.1 \pm 1$ & $7.58 \pm 0.1$ & $77.0 \pm 2^{*}$ & $8.0 \pm 1^{*}$ \\
$S N P$ & $99.0 \pm 0.3$ & $7.77 \pm 0.1$ & $57.5 \pm 2^{*}$ & $7.85 \pm 0.1^{*}$ \\
$S N P+B Q 123$ & $85.7 \pm 0.3$ & $7.10 \pm 0.04$ & $51.5 \pm 3^{*}$ & $8.15 \pm 0.12^{*}$ \\
\hline
\end{tabular}

Rmax, maximal relaxation; $\mathrm{pD}_{2}$, $-\log (\mathrm{EC} 50)$. Preactivation with Phe $(300 \mathrm{nM})$. Values are means $\pm \mathrm{SEM} . * \mathrm{p}<0.05$ vs. controls. Each group consisted of 8 arteries from control subjects and obese hypertensive patients, respectively.
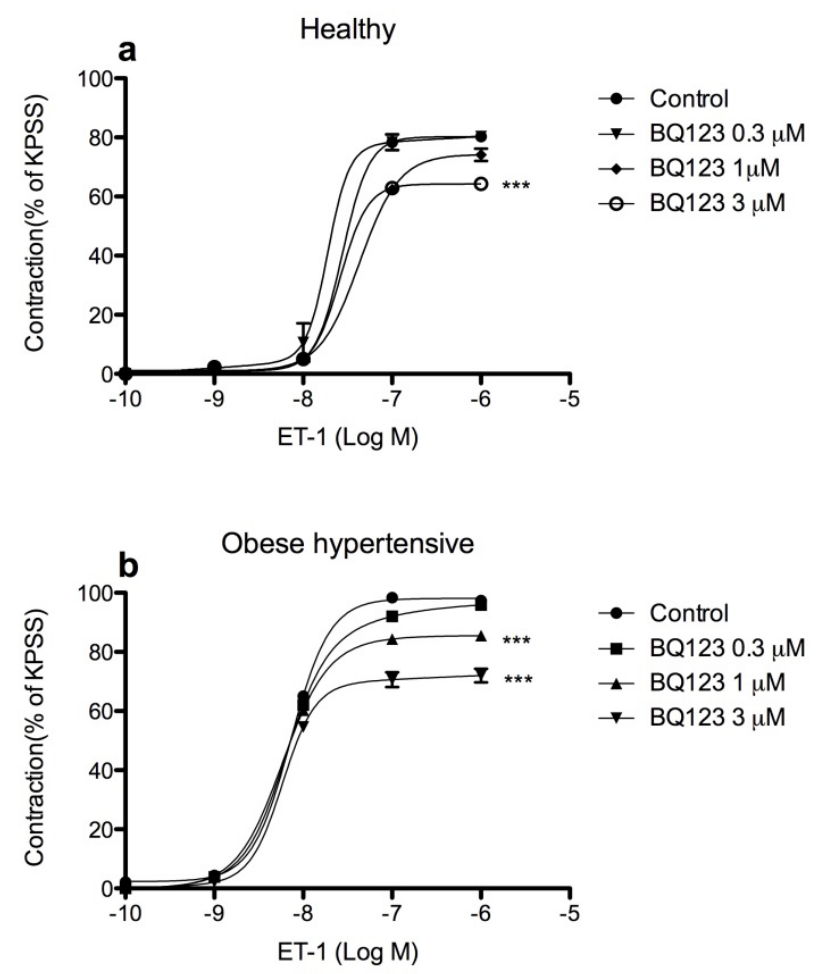

Fig. 1. Endothelin vasoconstriction of human small arteries in the absence and presence of three different concentrations of the $\mathrm{ET}_{\mathrm{A}}$ receptor antagonist BQ123: $0.3 \mu \mathrm{M}, 1 \mu \mathrm{M}$ and $3 \mu \mathrm{M}$. The arteries are precontracted with $124 \mathrm{mM}$ KPSS and relaxations are expressed as percentage of the initial constriction level. Values are means \pm SEM of arteries from 8 healthy subjects (a) and 8 obese hypertensive patients (b), respectively. Significantly different responses were evaluated by $t$ test: $* * * p<0.0001$.

\section{Response to ET-1}

ET-1 evoked more pronounced contraction in arteries from obese hypertensive patients than in arteries from healthy controls. The maximal contraction induced by ET-1 was $98.2 \pm 0.3 \%$ of KPSS in arteries from hypertensive patients vs. $85.8 \pm 0.5 \%$ in control arteries $(\mathrm{p}<0.001 ; \mathrm{n}=8)$. Furthermore, the concentration-response curve to ET-1 was shifted leftward in arteries from obese hypertensive compared to healthy control subjects
(Figs $1 \mathrm{a}$ and $1 \mathrm{~b}$ ). The $\mathrm{ET}_{\mathrm{A}}$ receptor antagonist BQ123 $(1 \mu \mathrm{M})$, inhibited these contractions, significantly in arteries from obese hypertensive patients whereas it did not significantly influence the contractions induced by ET-1 in arteries from healthy controls. The highest dose of $3.0 \mu \mathrm{M}$ inhibited the contractile responses in arteries from control subjects (Figs $1 \mathrm{a}$ and $1 \mathrm{~b}$ ).

\section{Vasodilator response to ACh and SNP}

The vasorelaxing effects were determined on arteries precontracted with Phe (300 $\mathrm{nM})$. The relaxation induced by ACh (0.1 nM - $0.1 \mathrm{mM})$ was significantly impaired in arteries from obese hypertensive patients in comparison with those from healthy controls. The NOS inhibitor L-NAME $(0.1 \mathrm{nM})$ significantly attenuated the relaxing effect of ACh in arteries from both healthy and obese hypertensive patients. Preincubation with the $\mathrm{ET}_{\mathrm{A}}$ receptor antagonist BQ123 $(1 \mu \mathrm{M})$ significantly enhanced the ACh induced relaxation in arteries from obese hypertensive patients with max value of (51 $\pm 2 \%$ to $77 \pm 2 \% ; n=8)$. In contrast, the relaxing effect of ACh in arteries from control subjects were unaffected by BQ123 $(1 \mu \mathrm{M})$. Furthermore, the ACh induced relaxation showed $\mathrm{pD}_{2}$ values for control and obese hypertensive arteries, respectively, and after BQ123 $(1 \mu \mathrm{M})$ antagonism (Table 2$)$. The response to L-NAME $(0.1 \mathrm{nM})$ were of similar magnitude in arteries from healthy and obese hypertensive patients (Figs $2 \mathrm{a}$ and $2 \mathrm{~b}$ ).

The NO donor SNP $(0.1 \mathrm{nM}-0.1 \mathrm{mM})$ induced relaxation of Phe (300 $\mathrm{nM}$ ) precontracted arteries and the response to the $\mathrm{ET}_{\mathrm{A}}$ receptor antagonist BQ123 $(1 \mu \mathrm{M})$ did not further modify the relaxation induced by SNP in arteries from obese hypertensive patients. The control response described a difference of the maximal response. Further, the SNP induced relaxation and vascular sensitivity, $\mathrm{pD}_{2}$, was more pronounced in arteries from healthy subjects (Table 2) (Figs 3a and 3b). 

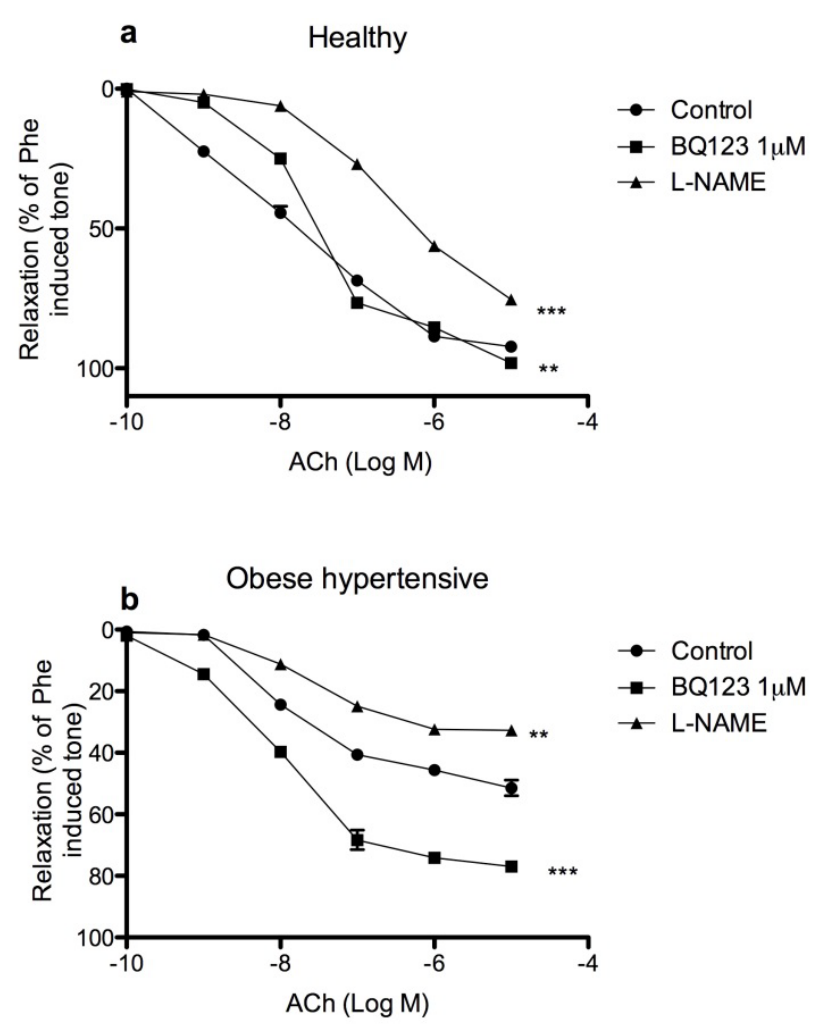

Fig. 2. ACh relaxation of human small arteries in the absence and presence of the $\mathrm{ET}_{\mathrm{A}}$ receptor antagonist BQ123 $(1 \mu \mathrm{M})$ or the NO synthase inhibitor L-NAME $(0.1 \mathrm{nM})$. The arteries were constricted with Phe $(300 \mathrm{nM})$ and relaxation are expressed as percentage of the initial constriction level. Data are means \pm SEM of arteries from 8 healthy subjects (a) and 8 obese hypertensive patients (b), respectively. Significantly different responses were evaluated by $\mathrm{t}$ test. $* * \mathrm{p}<0.001, * * * \mathrm{p}<0.0001$.

\section{Discussion}

The main finding is increased blood pressure, altered vascular response to ET-1 and endothelial dysfunction contribute to enhanced vasoconstriction in arteries from obese hypertensive woman, a response after post gastric bypass surgery. With menopause abdominal adiposity increase neurohormonal drive and nitric oxide contribute to the increased release of ET-1 and hypertension (Stein et al. 1998, Teeds et al. 2010). Previous studies show increased ET-1 levels after bypass surgery and increased blood pressure in obese hypertensive patients found in this study supports the prevalence of hypertension among obese subjects (Stauffer et al. 2008, Scheen and Luyckx 1999).

Obesity is one component of a risk factor constellation that consists of impaired glucose uptake, low density lipoprotein glyceride, cholesterol and triglyceride levels. Furthermore, decreased levels of HDL were found in samples from obese patients; however, the levels of LDL cholesterol were similar between the
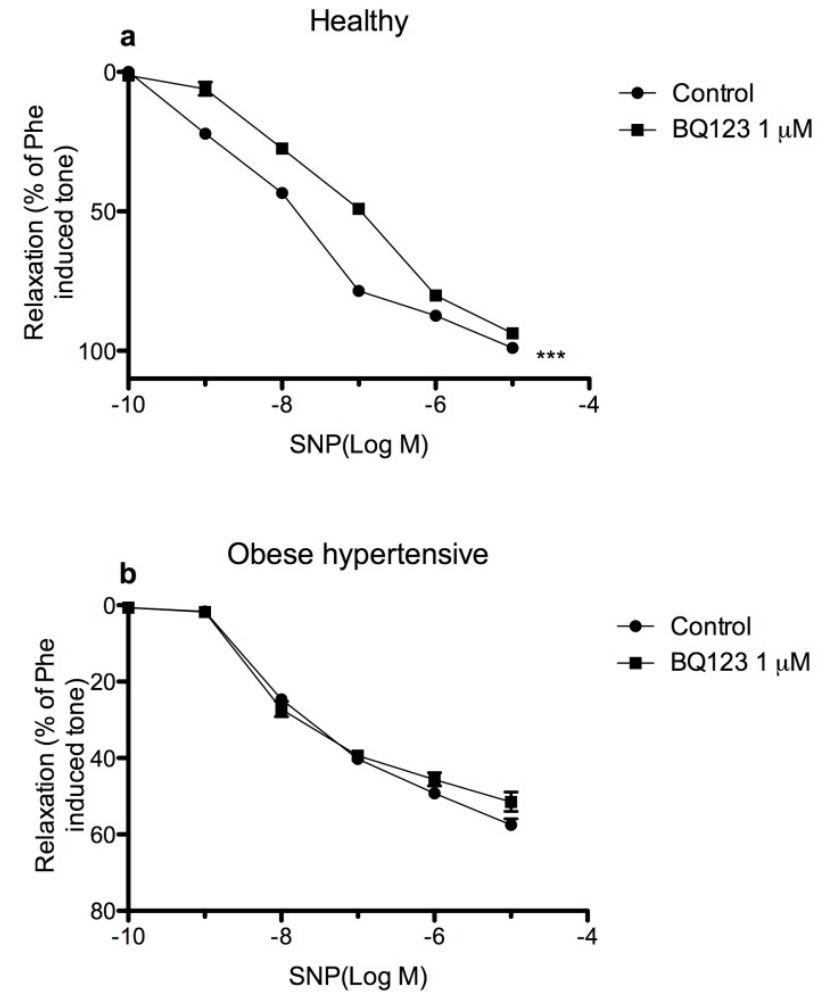

Fig. 3. SNP relaxation of human small arteries in the absence and presence of the $\mathrm{ET}_{\mathrm{A}}$ receptor antagonist $\mathrm{BQ123}(1 \mu \mathrm{M})$. The arteries were constricted with Phe $(300 \mathrm{nM})$ and relaxations are expressed as percentage of the initial constriction level. Data are means \pm SEM of arteries from 8 healthy subjects (a) and 8 obese hypertensive patients (b), respectively. Significantly different responses were evaluated by $t$ test. $* * p<0.001$.

groups. Interestingly similar levels of LDL are found in elder male patients with atherosclerosis and their controls (Böhm et al. 2002a). Also NO may contribute since it inhibits smooth muscle cell proliferation, thus protecting the wall against atherosclerosis (Jessup 1996, Pernow et al. 2012). Therefore both the duration of the increased blood pressure and morphological changes may contribute to the increased vasoconstrictor stimulus and endothelial dysfunction (Gibbons and Dzau 1994).

Our results show that after administration of the selective $\mathrm{ET}_{\mathrm{A}}$ receptor antagonist $\mathrm{BQ123}$ the vasodilator response to ACh was significantly enhanced in arteries from obese hypertensive patients compared to arteries from healthy patients. Further, after administration of L-NAME the vasodilator response was blocked. In order to support these findings administration of the NO donor, $\mathrm{SNP}$, did not significantly modify the $\mathrm{ET}_{\mathrm{A}}$ blockade in arteries from hypertensive patients. Thus supporting that endothelium-independent vasodilation was not influenced and that the VSMCs to relax did not differ between the 2 study groups (Böhm et al. 2002a). Previous results 
describe an improvement in endothelial vasodilator function after either non selective $\mathrm{ET}_{\mathrm{A} / \mathrm{B}}$, selective $\mathrm{ET}_{\mathrm{A}}$ or selective $\mathrm{ET}_{\mathrm{B}}$ blockade in segments of the internal mammary artery obtained from patients with various combinations of risk factors undergoing coronary artery bypass grafting in whom the ET-1 system is similarly attended (Hoogerwerf et al. 2001). Further, results report showing that ET-1 receptor antagonism is able to prevent upregulation of vascular ET-1 and correct endothelial dysfunction in an experimental model of hypertension (Verma et al. 2001). Since in endothelium denuded arteries ET-1 contraction is enhanced compared to arteries from normal patients (Ruscitzka et al. 2001, Verhaar et al. 1998). Therefore, in addition to endothelial cell dysfunction an increased smooth muscle activation appears to contribute to ET-1 contraction in arteries from obese hypertensive patients. NO antagonizes ET-release from the endothelium and $\mathrm{ET}_{\mathrm{B}}$ relaxant receptors may be involved in the contractile responses (Riezebos et al. 1994, Porteri et al. 2002, Stefano et al. 1999, Bigaud and Pelton 1992). Moreover, contractile responses to phenylephrine and serotonin are highly increased by NO synthase inhibition which through the endothelium regulates smooth muscle sensitivity to NO (Meininger and Davis 1992, Thorin et al. 1998). Accordingly, the improvement of ACh induced NO-dependent relaxation by blockade of $\mathrm{ET}_{\mathrm{A}}$ receptors was due to improvement of endothelial function. Therefore it seems reasonable to postulate that augmentation of NO activity is a likely mechanism for the improved endothelium-mediated vasorelaxation supported by results from Pussard et al. (1995).

In the present study, concentration-response curves for ET-1 were shifted leftward in arteries from obese hypertensive patients. The $\mathrm{ET}_{\mathrm{A}}$ receptor antagonist BQ123 antagonized the ET-1 contraction significantly further to the right in arteries from obese hypertensive patients compared to arteries from healthy subjects. Similar results have been found in forearm blood flow responses from hypertensive patients (Taddei et al. 2001, Cardillo et al. 2002, Rafnsson et al. 2012, Böhm et al. 2002b). Interestingly others have found that also blood pressure has been lowered substantially after administration of $\mathrm{ET}_{\mathrm{A} / \mathrm{B}}$ nonselective antagonists (Weil et al. 2011). Further, ET-1 may largely cause vasoconstriction and hypertension as shown by others (Zhu et al. 1999, Böhm et al. 2007). In the present study the nonparallel shifts in concentration response curves by BQ123 in arteries from obese hypertensive patients cannot be ascribed to the presence of endothelial receptors which oppose ET-1 contraction (Haynes and Webb 1994), since ET-1-induced contraction mediated by $\mathrm{ET}_{\mathrm{A}}$ receptors is considered to be endothelium independent (Spieker et al. 2006, Cardillo et al. 2002). Hereby, these results provide both indirect and direct evidence for endothelial cell dysfunction.

The main finding in the present study is increased blood pressure. Blockade of ET-1 receptors improves the endothelium dependent relaxation as well as reduces the alteration of the smooth muscle response to ET-1. The capacity of the ET-1 receptor antagonist to reduce vascular tone may represent an alternative treatment in cardiovascular disease and obese hypertension.

\section{Conflict of Interest}

There is no conflict of interest.

\section{Acknowledgements}

A sincere gratitude is conveyed for excellent advice to Prof. John Pernow and nurse Camilla Westerberg for kind assistance and support.

\section{References}

ANWAAR I, RENDELL M, GOTTSATER A, LINGARDE F, HULTHEN UL, MATTIASSON I: Hormone replacement therapy in healthy postmenopausal woman. Effects on intraplatelet cyclic guanosine monophosphate, plasma endothelin-1 and neopterin. J Intern Med 247: 463-470, 2000.

BIGAUD M, PELTON JT: Discrimination between $\mathrm{ET}_{\mathrm{A}}, \mathrm{ET}_{\mathrm{B}}$-receptors mediated effects of endothelin-1 and $\left(\right.$ Ala $^{1,3,11,15}$ ) endothelin-1 by BQ123 in the anaesthetized rat. Br J Pharmacol 107: 912-918, 1992.

BÖHM F, PERNOW J: The importance of endothelin-1 for vascular dysfunction in cardiovascular disease. Cardiovasc Res 76: 8-18, 2007.

BÖHM F, AHLBORG G, JOHANSON BL, HANSSON LO, PERNOW J: Combined endothelin receptor blockade evokes enhanced vasodilatation in patients with atherosclerosis. Arterioscler Thromb Vasc Biol 22: 674-679, 2002a. 
BÖHM F, AHLBORG G, PERNOW J: Endothelin-1 inhibits endothelium-dependent vasodilatation in the forearm: reversal by $\mathrm{ET}_{\mathrm{A}}$ receptor blockade in patients with atherosclerosis. Clin Sci 102: 321-327, $2002 \mathrm{~b}$.

CARDILLO C, CAMPIA U, KILCOYNE C, BRYANT M, PANZA J: Improved endothelium dependent vasodilation after blockade of endothelin receptors in patients with essential hypertension. Circulation 105: 452-456, 2002.

CELEMAYER DS, SORENSEN KE, SPIEGELHALTER DJ, GEORGAKOPOULES D, ROBINSON J, DEANFIELD JE: Aging is associated with endothelial dysfunction in healthy men years before the age-related decline in woman. J Am Coll Cardiol 24: 471-476, 1994.

DERBYSHIRE ER, MARIETTA MA: Structure and regulation of soluble gyanylate cyclase. Annu Rev Biochem 81: 533-559, 2012.

D'ORLEANS-JUSTE P, LABONTE J, BKAILY G, CHOUFANI S, PLANTE M, HONORE JC: Function of the endothelin (B) receptor in cardiovascular physiology and pathophysiology. Pharmacol Ther 95: 221-238, 2002.

GIBBONS GH, DZAU VJ: The emerging concept of vascular remodelling. N Engl J Med 330: 1431-1438, 1994.

GRADIN KA, LI Y, ANDERSSON O, SIMONSEN O: Enhanced neuropeptide Y immunoreactivity and vasoconstriction in mesenteric small arteries from spontanously hypertensive rats. J Vasc Res 40: 252-265, 2003.

HAYNES WG, WEBB DJ: Contribution of endogenous generation of endothelin-1 to basal vascular tone. Lancet $\mathbf{3 4 4}$ : 852-854, 1994.

HOOGERWERF N: A role for endothelin receptor blockade in improving the endothelial function of coronary artery grafts. Cardiovasc Res 49: 15-16, 2001.

JESSUP W: Oxidized lipoproteins and nitric oxide. Curr Opin Lipidol 7: 274-280, 1996.

LUSCHER TF, NOLL G: The pathogenesis of cardiovascular disease: role of the endothelium as a target and mediator. Atherosclerosis 118 (Suppl): S81-S90, 1995.

MAGUIRE JJ, KUC RE, DAVENPORT AP: Vasoconstrictor activity of novel endothelin peptide, ET-1 (1-31), in human mammary and coronary arteries in vitro. Br J Pharmacol 34: 1360-1366, 2001.

PANZA JA, QUYUMI AA, BRUSH JE: Abnormal endothelium-dependent relaxation in patients with essential hypertension. $N$ Engl J Med 323: 22-27, 1990.

PANZA JA, CASINO PR, KILCOYNE CH: Role of endothelium-derived nitric oxide in the abnormal endotheliumdependent vascular relaxation in patients with essential hypertension. Circulation 87: 1468-1474, 1993.

PERNOW J, SHEMYAKIN A, BÖHM F: New perspectives on endothelin-1, atherosclerosis and diabetes mellitus. Life Sci 91: 507-516, 2012.

PORTERI E, RIZZONI D, GUELFI D, DE CC, CASTELLANO M, BETTONI G, TIBERIO GA, GUILINI SM, SLEIMAN I, AGABITI-ROSEI E: Role of ET(A) receptors in the vasoconstriction induced by endothelin-1 in subcutaneous small arteries of normotensive subjects and hypertensive patients. Blood Press 11: 6-12, 2002.

QIAO X, MCCONNELL KR, KHALIL RA: Sex steroids and vascular responses in hypertension and aging. Gend Med 5 (Suppl 1): S46-S64, 2008.

RAFNSSON A, BÖHM F, SETTERGREN M, GONON A, BRISMAR K, PERNOW J: The endothelin receptor antagonist bosentan improves peripheral endothelial function with type 2 diabetes mellitus and microalbuminuria: a randomised trial. Diabetologia 55: 600-607, 2012.

RUSCHITZKA F, QUASCHNING T, NOLL G, DEGOTTARDI A, ROSSIER MF, ENSELEIT F, HÜRLIMANN D, LÜSCHER TF, SHAW SG: Endothelin type A receptor antagonism prevents vascular dysfunction and hypertension induced by 11beta-hydroxysteroid dehydrogenase inhibition: role of nitric oxide. Circulation 103: 3129-3135, 2001.

SAKUARI T, YANAGISAWA M, TAKUWA Y: Cloning of a cDNA encoding a nonisopeptide-selective subtype of the endothelin receptor. Nature 348: 732-735, 1990.

SCHEEN AJ, LUYCKX FH: Medical aspects of obesity. Acta Chir Belg 99: 135-139, 1999.

SPIEKER LE, FLAMMER AJ, LUSCHER TF: The vascular endothelium in hypertension. Handb Exp Pharmacol 176: 249-283, 2006.

STAUFFER BL, WESTBY CM, DE SOUZA CA: Endothelin 1, aging and hypertension. Curr Opin Cardiol 23: 350-355, 2008. 
STEFANO TA, VINDIS A, GHIADONI L, SUDANO I, NOTARI M, SOLVETTI A: Vasoconstriction to endogenous endothelin-1 is decreased in the peripheral circulation of patients with essential hypertension. Circulation 100: 1680-1683, 1999.

STEIN B, ESCHENHAGEN T, RUDIGER J, SCHOLTZ H, FÖRSTERMANN U, GATH I: Increased expression of constitutive nitric oxide synthase III, but not inducible nitric oxide synthase II, in human heart failure. $J$ Am Coll Cardiol 32: 1179-1186, 1998.

STORK S, VAN DER SCHOUW YT, GROBBEE DE, BOTS ML: Estrogen, inflammation and cardiovascular risk in woman: a critical appraisal. Trends Endocrinol Metab 15: 66-72, 2004.

TADDEI S, VIRDIS A, GHIADONI L, SUDAO I, MAGAGNA A, SALVETTI A: Role of endothelin in the control of peripheral vascular tone in human hypertension. Heart Fail Rev 6: 277-285, 2001.

TANG EH, VANHOUTTE PM: Endothelial dysfunction: a strategic target in the treatment of hypertension. Pflugers Arch 459: 995-1004, 2012.

THORIN E, NGUYEN TD, BOUTHILLIER A: Control of vascular tone by endogenous endothelin-1 in human pial arteries. Stroke 29: 175-180, 1998.

VERHAAR MC, STRACHAN F, NEWBY DE: Endothelin-A receptor antagonist-mediated vasodilation is attenuated by inhibition of nitric oxide synthesis and by endothelin-B receptor blockade. Circulation 97: 752-756, 1998.

VERMA S, LOVREN F, DUMANT AS: Endothelin-receptor blockade improves endothelial function in human internal mammary arteries. Cardiovasc Res 49: 146-151, 2001.

WARNER TD: Relationships between the endothelin and nitric oxide pathways. Clin Exp Pharmacol Physiol 26: 247-252, 1999.

WEIL BR, WESTBY CM, VAN GUILDER GP, GREINER JJ, STAUFFER BL, DESOUZA CA: Enhanced endothelin-1 system activity with overweight and obesity. Am J Physiol Heart Circ Physiol 301: H689-H695, 2011.

YANAGISAWA M, KURIHARA H, KIMURA S, TOMOBE Y, KOBAYASHI M, MITSUL Y, YASAKI Y, GOTO K, MASAKI T: A novel potent vasoconstrictor peptide produced by vascular endothelial cells. Nature 332 : 411-415, 1988.

ZHU P, DETTMANN ES, RESINK TJ, LUSCHER TF, FLAMMER J, HAEFLIGER IO: Effect of Ox-LDL on endothelium-dependent response in pig ciliary artery: prevention by an $\mathrm{ET}_{\mathrm{A}}$-antagonist. Invest Ophthalmol Vis Sci 40: 1015-1020, 1999. 